\title{
CLINICAL AND RADIOGRAPHIC EVALUATION OF A POLYESTER PROSTHESIS IN DOGS WITH CRANIAL CRUCIATE LIGAMENT RUPTURE
}

\author{
CLÍNICA E RADIOGRAFIA DA PRÓTESE DE POLIÉSTER EM CÃES \\ COM RUPTURA DO LIGAMENTO CRUZADO CRANIAL
}

\section{André Luis Selmi ${ }^{1}$ João Guilherme Padilha Filho ${ }^{2}$ Glenda Ramalho Barbudo ${ }^{1}$ Luiz Eduardo Carvalho Buquera ${ }^{3}$ Júlio Carlos Canola ${ }^{2}$}

\section{SUMMARY}

Clinical and radiographic findings after intraarticular replacement of cranial cruciate ligament with a polyester prosthesis using a modified over-the-top technique were evaluated in six dogs. Seven surgeries were done due to bilateral involvement of the cranial cruciate ligament in one dog. Clinical evaluation was performed on postoperative days 3, 10 and 40, and radiographic evaluation was done at 5 and 24 months after surgery in five dogs, where signs of progressive degenerative joint disease were confirmed. Resolution of clinical signs was observed from 25 to 68 days after surgery as evaluated by dog owners. Overall function of joint movement after surgery was classified as good. Two dogs presented fraying of the implant after surgery. It was concluded that the polyester prosthesis, as implanted in these dogs, was not a satisfactory replacement for the injured ligament, as better results may be obtained withless invasive and simpler techniques.

Key words: polyester prosthesis, cranial cruciate ligament, dog.

RESUMO

Os achados clínicos e radiográficos após reparo intra-articular do ligamento cruzado cranial com prótese de poliéster, utilizando a técnica over-the-top modificada, foram avaliada em seis cães. Sete cirurgias foram realizadas devido ao acometimento bilateral em um dos animais. A avaliação clínica foi realizada ao $30,10^{\circ}$ e $40^{\circ}$ dias de pós-operatório, e a avaliação radiográfica realizada ao $5^{\circ}$ e $24^{\circ}$ meses após a cirurgia em cinco cães, por meio da qual se confirmou a progressão da doença articular degenerativa. A resolução dos sinais clínicos foi observada entre o $25^{\circ}$ e 68ㅇa dias após a cirurgia, segundo avaliação realizada pelos proprietários. A função do membro operado foi considerada boa. Dois cães apresentaram desgaste e ruptura da prótese após a cirurgia. Concluiu-se que a prótese de poliéster, da forma como foi implantada neste estudo, não pode ser considerada como substituto satisfatório, uma vez que resultados superiores podem ser obtidos com ténicas menos invasivas e mais simples.

Palavras-chave: prótese de poliéster, ligamento cruzado cranial, cão.

\section{INTRODUCTION}

Rupture of the cranial cruciate ligament (CCL) is among the most common causes of hindlimb lameness in the dog (AIKEN et al., 1992; VASSEUR 1993; MOORE \& READ 1996a; VASSEUR et $\boldsymbol{a l}$., 1996), and contralateral rupture of the $\mathrm{CCl}$ may affect $30 \%$ of dogs presented initially (DOVERSPIKE et al., 1993; HARASEN, 1995).

Clinical signs vary among dogs but hindlimb lameness is a frequent finding. Older dogs may present an insidious episode of lameness

\footnotetext{
${ }^{1}$ Médico Veterinário, Mestre. Aluno do Curso de Pós-graduação em Cirurgia Veterinária, Universidade Estadual Paulista (UNESP), Faculdade de Ciências Agrárias e Veterinárias (FCAV) de Jaboticabal. Professor. Universidade de Brasília, Faculdade de Agronomia e Medicina Veterinária, Campus Darcy Ribeiro, CP 04508, asa Norte, 70910-970, Brasília, DF. E-mail: selmi@unb.br. Autor para correspondência.

${ }^{2}$ Médico Veterinário, Doutor. Professor Assistente, UNESP, FCAV de Jaboticabal. Departamento de Clínica e Cirurgia Veterinária. Rodovia Professor Paulo Donato Castelane, s/n, 14870-000, Jaboticabal, SP, Brasil.

${ }^{3}$ Médico Veterinário, Mestre, Aluno do Curso de Pós-graduação em Cirurgia Veterinária, UNESP, FCAV.
} 
probably associated with degenerative changes within the joint prior to CCL rupture (DENNY, 1993). Pain is normally observed during palpation after a traumatic rupture (MOORE \& READ, 1996b) and dogs will start to use the limb again within two to three weeks; however, as degenerative joint disease (DJD) progresses, hindlimb lamenes will become evident. DJD may be present at the time of rupture (MOORE \& READ, 1996b) or result from instability caused by primary incompetence of the CCL (ELKINS et al., 1991; VASSEUR \& BERRY, 1992; FITCH et al., 1995; METELMAN et al., 1995).

Cranial drawer sign is normally present in a CCL-deficient stifle and diagnosis of a ruptured ligament is confirmed after arthrotomy (HULSE, 1995; MOORE \& READ, 1996b; PIERMATTEI \& FLO, 1997). Recent studies have shown that radiographic evaluation of affected joints does not consistently assess joint instability ROOSTER \& VAN BREE, 1999), but it may be indicated to evaluate secondary degenerative changes within the joint (HULSE, 1995; RACKARD, 1996).

Non-surgical treatment of CCL ruptures may be effective in dogs weighing less than $15 \mathrm{~kg}$ (VASSEUR, 1984), however, heavier or active dogs will benefit from surgical stabilization of the affected joint (HULSE, 1995; MOORE \& READ, 1996a; PIERMATTEI \& FLO, 1997). Described surgical techniques are divided into two major groups: intra or extra-articular procedures. Extraarticular echniques rely on placement of a lateral band of biological tissue or synthetic material for limiting cranial translation and internal rotation of the tibia, resulting in periarticular fibrosis (AIKEN et al., 1992; RACKARD, 1996; VASSEUR et al., 1996), whereas intra-articular repair is theoretically preferable as it provides a more accurate function of the created neoligament (ARNOCSKY, 1996; VASSEUR et al., 1996).

Materials used as substitutes for the ruptured $\mathrm{CCl}$ include autogenous fascia lata (ELKINS et al., 1991; ARNOCSKY, 1993; COETZEE \& LUBBE, 1995; METELMAN et al., 1995; MOORE \& READ, 1996a) and synthetic replacements (MOORE \& READ, 1996a, VASSEUR et al., 1996; CAMARGO et al., 2001). Synthetic materials are advantageous in comparison with biological materials because they can be made to meet requirements of intra-articular placement and surgery is less traumatic as it is related to collection of biological grafts (VASSEUR et al., 1996). The Leeds-Keio implant was experimentally used in dogs (FUJIKAWA \& ISEKI, 1991; VASSEUR $\boldsymbol{e} \boldsymbol{t} \boldsymbol{a l} ., 1996)$ and sheep (SCHINDHELM et al., 1991) with the purpose of serving as a scaffold for ingrowth of pre-placed autogenous tissue resulting in formation of a biological ligament.

The purpose of this study was to evaluate the dinical and radiographic results after repairing of the CCL-deficient stifle in dogs using a polyester prostheses.

\section{MATERIALS AND METHOD}

\section{Case details and evaluation}

This study was conducted in six consecutive dogs suspected of having cranial cruciate ligament rupture presented to the Veterinary Teaching Hospital of the Universidade Estadual Paulista at Jaboticabal, state of São Paulo, Brazil. Data obtained from clinical files included breed, sex, body weight, age at presentation, clinical signs, duration of symptoms and previous treatments. Clinical diagnosis was based in the presence of hindlimb lameness associated with a positive cranial drawer sign. Rupture of the cranial cruciate ligament was confirmed during exploratory arthrotomy.

The degree of lameness was recorded and classified as: grade 0 (free of lameness), grade 1 (lameness only after exercise), grade 2 (weightbearing with intermitent lameness), grade 3 (continuous weight-bearing lameness) and grade 4 (non-weight-bearing lameness). Radiographs taken in cranio-caudal and medio-lateral projections were used to assess any secondary osteoarthritic changes at the time of presentation and after surgery. Degenerative changes were classified according to COETZEE \& LUBBE (1995) as: absent (no osteophytes), mild (osteophytes visible on the patella only), moderate (osteophytes on the patella and trochlear ridges of the femur) and severe (severe osteophyte formation, sclerosis and irregularities on the fabelllae).

\section{Surgical procedure}

Dogs were anesthetized and the affected limb prepared for asseptic surgery. Amoxicilinclavulanate $^{\mathrm{a}}$ was given subcutaneously and flunixin meglumine ${ }^{b}$ was given intravenously at the time of induction. A lateral parapatellar approach to the joint was used. After incision of the joint capsule, the patella was luxated medially for exploration of the joint. Remnants of the cranial cruciate ligaments were excised and the joint flushed with $0,9 \%$ saline. A tibial tunnel was prepared by drilling a hole in the cranio-medial portion of the tibial insertion of the CCL so that the distal portion of the hole emerged in the medial aspect of the proximal tibial metaphysis. 
A drill hole was then made in the lateral aspect of the lateral femoral condyle and one of the extremities of the prosthesis ${ }^{c}$ was secured in place with a washer and screw. The free end of the prosthesis was directed from caudal to cranial, over the top of the lateral femoral condyle, emerging in the intercondylar fossa, passing through the tibial tunnel, pulled snugly from within the joint, and fixed in place with a washer and a screw with the limb in external rotation and slight flexion, while the tibia was pushed caudally.

After thorough lavage of the joint with $0.9 \%$ saline, the joint capsule was closed using polyglactin $^{\mathrm{d}}$ in a simple continuous pattern. The retinaculum was sutured in a similar manner using a polydioxanone $\mathrm{e}^{\mathrm{e}}$ suture. Subcutaneous and skin were sutured in a routine manner. Limbs were not bandaged after the surgery and dogs were dismissed from hospital immediately after recovery from anesthesia. Owners started passive range of motion at postoperative day 1. Exercise was limited to leash walks for 6 weeks after surgery.

Dogs were evaluated clinically on postoperative days 3, 10 and 40. In four animals, clinical and radiographic evaluations were performed at 5 and 24 months after surgery.

\section{RESULTS}

All dogs had a complete rupture of the CCL as observed intra-operatively. In this study, seven joints were operated, as dog \# 2 presented a contralateral rupture 4 months after initial presentation. The mean age of dogs was $4.8 \pm 0.48$ years with a mean body weight of $40 \pm 16.5 \mathrm{~kg}$. Equal distribution of males and females was observed. Dogs did not present a meniscus lesion at time of surgery. Dog \# 1 was presented seven months after initial surgery with ipsilateral hindlimb lameness and was submitted to an exploratory stifle arthrotomy. Rupture of the polyester prostheses was observed and a lateral fabellotibial suture was used to stabilize the joint. Dog \# 5 died 18 months after initial surgery from unrelated causes and at necropsy, severe osteophytosis and complete rupture of the prostheses was observed. In both cases where rupture of the prosthesis was observed, it occurred proximal to the insertion at the tibial tunnel.

On presentation, one dog presented grade 1 lameness, two had grade 2 lameness and three had grade 3 lameness (Table 1). A positive cranial drawer sign was observed in all affected stifles in both extension and flexion, indicating complete rupture of the CCL.

Dogs were bearing weight on the operated limbs 3 to 10 days after surgery. Cranial drawer sign was not observed at this time interval, however, by day 40 postoperatively, it increased in all of the stifles as compared to immediate postoperative evaluation. Limb use was consistently poorer on postoperative day 3 , but it progressively improved after 10 to 40 days when lameness was absent in three dogs and had diminished by at least one grade in the others (Table 1). Continuous weight-bearing was observed starting from day 25 to 68 as reported by owners. Dogs \# 1, 2, and 3 were clinically and radiographically assessed at 5 and 24 months after surgery. Dogs \# 4 and 6 were not evaluated at 5 months but were at 24 months postoperatively. Dog \# 1 was also evaluated seven months after initial surgery. All dogs were classified as having good limb function according to their owners, however, joint laxity accompanied by crepitation and diminished range of motion was observed in all dogs. Pain was not elicited on manipulation of the operated joints. Thickening of medial aspect of the joint was observed in all dogs. Dog \# 1 was clinically normal 19 months after the extra-articular fabello-tibial suture.

Signs of degenerative joint disease were present in different degrees but in one $\operatorname{dog}(\operatorname{dog} \# 1)$ at initial presentation. Three dogs had a mild

Table 1 - Data summary of patients treated with a polyester prosthesis for surgical stabilization of cranial cruciate-deficient stifle.

\begin{tabular}{lcccccc}
\hline DOG \# & 1 & 2 & 3 & 4 & 5 & 6 \\
\hline SEX & $\mathrm{F}$ & $\mathrm{M}$ & $\mathrm{F}$ & $\mathrm{M}$ & $\mathrm{M}$ & $\mathrm{F}$ \\
AGE (YEARS) & 5 & 4.3 & 4.2 & 4.8 & 5.5 & 5 \\
WEIGHT (KG) & 46 & 34 & 19 & 32 & 68 & 41 \\
TIME FROM INJURY TO PRESENTATION(DAYS) & 2 & 4 & 14 & 21 & 3 & 20 \\
LAMENESS AT PRESENTATION (GRADE) & 2 & 3 & 1 & 2 & 3 & 3 \\
LAMENESS AT DAY 3 (GRADE) & 3 & 3 & 2 & 2 & 4 & 3 \\
LAMENESS AT DAY 10 (GRADE) & 2 & 2 & 2 & 2 & 3 & 2 \\
LAMENESS AT DAY 40 (GRADE) & 1 & 0 & 0 & 0 & 1 & 1 \\
DJD AT PRESENTATION & $\mathrm{A}$ & $\mathrm{MI}$ & $\mathrm{MI}$ & $\mathrm{MI}$ & $\mathrm{MO}$ & $\mathrm{MO}$ \\
DJD AFTER SURGERY (5 MONTHS) & $\mathrm{MO}$ & $\mathrm{MO}$ & $\mathrm{MI}$ & $\mathrm{N} / \mathrm{A}$ & $\mathrm{SE}$ & $\mathrm{N} / \mathrm{A}$ \\
DJD AFTER SURGERY (24 MONTHS) & $\mathrm{MO}$ & $\mathrm{MO}$ & $\mathrm{MO}$ & $\mathrm{MO}$ & $\mathrm{N} / \mathrm{A}$ & $\mathrm{MO}$
\end{tabular}

A - absent; Mi - mild; Mo - moderate; Se - severe; F - female; $\mathrm{M}$ - male; grade 1: lameness only after execise; grade 2: weight-bearing with intermitent lameness; grade 3: continuous weight-bearing lameness; grade 4: non-weight-bearing lameness; Djd - degenerative joint disease; N/A - not available. 
osteophytosis, whereas two had a moderate lesion. Radiographic signs of progression of degenerative changes at 5 and 24 months after surgery were observed in five dogs by at least one grade (Table 1).

A limb bandage was not applied postoperatively in order to allow early mobilization of the operated limbs.

\section{DISCUSSION}

This study suggests that the use of a polyester prosthesis is not a satisfactory replacement for the cruciate ligament, as observed by VASSEUR et al. (1996) using similar prostheses in a canine model. CAMARGO et al. (2001) recently described lack of satisfactory results using the same prostheses in human patients.

Succesful management of a ruptured cranial cruciate ligament depends upon the re-establishment of joint stability. Factors as mechanical properties of the graft, the type of graft-bone fixation, isometricity, tension applied to the autograft during fixation and filling of the intercondylar fossa with osteophytes may influence the outcome (COETZEE \& LUBBE, 1995; FITCH et al., 1995; VASSEUR et al., 1996). Ideally, the initial mechanical strenght of the synthetic graft should be great enough to maintain an adequate degree of stability as peri-articular fibrosis may ultimately provide the final stabilization of surgically treated stifles.

Considering the fact that a similar implant known as the Leeds-Keio prostheses was not intended to be a permanent replacement for the CCL (FUJIKAWA \& ISEKI, 1991; VASSEUR et al., 1996), it is important that the stifle is returned to a relatively stable condition while fibrosis of the joint capsule occurs.

Complete rupture of the Leeds-Keio implant in dogs has been attributed to excessive strain during joint flexion as a result of incorrect isometric placement (VASSEUR et al., 1996). Cruciate ligaments have a multi-bundle design so each fiber bundle is stressed or relaxed during a particular joint movement (ARNOCSKY, 1996). Correct isometric placement of the grafts may not be possible because the cruciate ligament has a multi-bundle design, therefore a ligament substitute would need to have a similar design in which each bundle would work independently. Also, isometric placement of implants implicates that the graft would be under even tension at all degrees of joint movement, however, the prosthesis used in this study is not constructed as an independent collection of bundles, therefore, some portion of the implant would be subjected to excessive strain during joint motion.
Other causes for implant failure are abrasion of the implants at the margin of the drill holes (VASSEUR et al., 1996; CAMARGO $\boldsymbol{e t}$ al., 2001) or filling of the intercondylar fossa with osteophytes (FITCH et al., 1995). Notchplasty is performed commonly in human patients to minimize impingement of the graft during extremes of joint motion (VASSEUR \& BERRY, 1992). By using an over-the-top procedure and not drilling a femoral tunnel, as described by VASSEUR et al. (1996), less contact of the prosthesis and bone was achieved. According to ARNOCSKY (1996) this approach would also place the graft as close to the isometric condition as possible. In this clinical study, despite the fact that neither rounding of the edges of the tibial drill holes nor notchplasty were performed, results were similar to that described by VASSEUR et al. (1996) and CAMARGO et al. (2001) who observed complete rupture or fraying of the implants. In the two cases where rupture of the prostheses was observed, it occurred just proximal to the tibial tunnel. Abrasion at the tibial drill holes could be implied as the cause for this complication. However, excessive cyclic deformation compressing the caudal portion of the prosthesis against the tibial plateau during flexion could explain the mode of failure observed in this study. Beveling of the tibial tunnel could have been beneficial in preventing this complication. In spite of the small number of clinical cases in this study, or experimental situations, at what point notchplasties would be beneficial in preventing implant failure in the dog is still unclear.

Signs of progression of degenerative joint disease are commom in radiographic studies concerning the postoperative evaluation of stifle surgery (ELKINS et al., 1991; VASSEUR \& BERRY, 1992; DOVERSPIKE et al., 1993; CHAUVET et al., 1996; VASSEUR et al., 1996; ROOSTER \& Van BREE, 1999). Progression of osteophytosis following implantation of the polyester prosthesis in dogs therefore demonstrates that the technique is not adequate in preventing joint instability as observed by VASSEUR et al. (1996) and CAMARGO et al. (2001) when using a similar prosthesis.

A positive cranial drawer sign is the most important finding in a dog with a ruptured cranial cruciate ligament, and immediate evaluation following surgery usually reveals a stable joint. However, as limb use improves, more weight is put on it and the implant becomes more prone to deformation, which usually is observed as joint laxity at subsequent evaluations following surgical treatment. Unsufficiently secure methods of fixation of the graft, stretching, fraying or deformation as well as complete rupture have been implicated as 
causes of increased joint instability in the long-term evaluation (AIKEN et al., 1992; COETZEE \& LUBBE, 1995; VASSEUR et al., 1996).

Clinical evaluation of gait in dogs might present errors, as the mood of the dog, location of testing, weather and many other factors can affect arthritic pain besides being a subjective evaluation of lameness (CHAUVET et al., 1996). Thus, improvement in gait, as observed in this study, simply demonstrates adaptation from individual dogs to the condition where shifting the weight could result in a better clinical evaluation, or it could represent stability after joint capsule tickening, or both. Although dogs in this study presented mild cranial drawer instability, crepitus and reduced range of motion following surgery, limb usage and degree of lameness were considered satisfactory, which is consistent with other study that showed poor correlation between presence of degenerative changes and clinical lameness (AIKEN et al., 1992).

Ingrowth of autogenous tissue around the synthetic replacement for the cranial cruciate ligament has been observed (FUJIKAWA\& ISEKI, 1991; SCHINDHELM et al., 1991). Evaluation of tis sue ingrowth was not intended in this clinical study, however, as observed by CAMARGO $\boldsymbol{e t}$ al . (2001) formation of a neoligament around the implant was not observed in the two cases that were available for macroscopic examination.

Dog \# 1 was treated after rupture of the polyester prosthesis by means of a lateral fabellotibial suture and did not show any complication after the second surgery; however, conclusions cannot be made due to the limited number of dogs that required a second surgery in the same limb, and variability of the care after surgery.

In conclusion, the polyester prosthesis used in this study did not prevent joint instability and progression of DJD, and could not be considered a satisfactory replacement for the cranial cruciate ligament in dogs as simpler techniques present comparable results.

\section{SOURCES AND MANUFACTURERS}

${ }^{a}$ Clavamox; Smithkline Beecham.

b Banamine; Schering-Plough.

${ }^{\mathrm{c}}$ Prótese Engimplan; Engimplan.

${ }^{\mathrm{d}}$ Vicryl; Ethicon.

e PDS II; Ethicon.

\section{REFERENCES}

AIKEN, S.W., BAUER, M.S., TOOMBS, J.P. Extra-articular fascial strip repair of the cranial cruciate deficient stifle: technique and results in seven dogs. Veterinary and Comparative Orthopedics and Traumatology, v. 5, p.145-150, 1992.
ARNOCSKY, S.P. Pathomechanics of cruciate ligament and meniscal injuries. In: BOJRAB, M.J. Disease mechanisms in small animal surgery. 2.ed. Philadelphia : Lea \& Febiger, 1996. Cap.110. p.764-776.

CAMARGO, O.P.A., SEVERINO, N.R., AIHARA, T., et $\boldsymbol{a l}$. Resultado a médio prazo da reconstrução da lesão crônica do ligamento cruzado anterior com prótese de poliéster. Revista Brasileira de Ortopedia, v.36, n.4, p.111-116, 2001.

CHAUVET, A.E., JOHNSON, A.L., PIJANOWSKI, G.J., et al Evaluation of fibular head transposition, lateral fabellar suture, and conservative treatment of cranial cruciate ligament rupture in large dogs: a retrospective study. Journal of the American Animal Hospital Association, v.32, p.247-255, 1996.

COETZEE, G.L., LUBBE, A.M. A prospective study comparing two fascial reconstruction techniques to stabilize the cranial cruciate deficient stifle in the dog. Veterinary and Comparative Orthopedics and Traumatology, v.8, p.18-26, 1995.

DENNY, H.R. A guide to canine and feline orthopaedic surgery. 3.ed. Oxford : Blackwell, 1993. The hindlimb: p. $355-364$.

DOVERSPIKE, M., VASSEUR, P.B., HARB, M.F., et al. Contra-lateral cranial cruciate ligament rupture: incidence in 114 dogs. Journal of the American Animal Hospital Association, v.29, p.167-170, 1993.

ELKINS, A.D., PECHMAN, R., KEARNEY, M.T., $\boldsymbol{e}$ t al. Retrospective study evaluating the degree of degenerative joint disease in the stifle joint of dogs following surgical repair of anterior cruciate ligament rupture. Journal of the American Animal Hospital Association, v.27, p.533-540, 1991.

FITCH, R.B., MONTGOMERY, R.D., KINCAID, S.A., $\boldsymbol{e}$ t al The effect of intercondylar notchplasty on the normal canine stifle. Veterinary Surgery, v.24, p.156-164, 1995.

FUJIKAWA, K., ISEKI, F. Anterior cruciate ligament reconstruction with the Leeds-Keio atificial ligament. Bulletin for Hospital for Joint Diseases and Orthopedic Instrumentation, v.51, p.140-154, 1991.

HARASEN, G.L.G. A retrospective study of 165 cases of rupture of canine cranial cruciate ligament. Canadian Veterinary Journal, v.36, p.250-251,1995.

HULSE, D.A. Ligament injuries of the stifle joint. In: OLMSTEAD, M.L. Small animal orthopedics. St.Loui s: Mosby Year Book, 1995. The stifle: p.404-501.

METELMAN, L.A., SCHWARZ, P.D., SALMAN, M., et al. An evaluation of three different cranial cruciate ligament surgical stabilization procedures as they relate to postoperative meniscal injuries. Veterinary and Comparative Orthopedics and Traumatology, v.8, p.118-123, 1995.

MOORE, K.W., READ, R.A. Rupture of the cranial cruciate ligament in dogs-part I. Compendium of Continuing Education for the Practicing Veterinarian, v.18, p.223234, 1996a.

MOORE, K.W., READ, R.A. Rupture of the cranial cruciate ligament in dogs -part II - diagnosis and management. Compendium of Continuing Education for the Practicing Veterinarian, v.18, p.381-391, 1996b. 
PIERMATTEI, D.L., FLO, G.L. Handbook of small animal orthopedics and fracture treatment. 3.ed. Philadelphia : Saunders, 1997. The stifle joint: p.516-580.

RACKARD, S. Cranial cruciate ligament rupture in the dog. Irish Veterinary Journal, v.49, p.481-484, 1996.

ROOSTER, H., VAN BREE, H. Radiographic measurement of craniocaudal instability in stifle joints of clinically normal dogs and dogs with injury of a cranial cruciate ligament. American Journal of Veterinary Research, v.60, p.1567$1570,1999$.

SCHINDHELM, K., ROGERS, G.J., MILTHORPE, B.K., et al Autograft and Leeds-Keio reconstruction of the ovine anterior cruciate ligament. Clinical Orthopedics, v.267, p.278-293, 1991.
VASSEUR, P.B. Clinical results following non-operative management for rupture of the cranial cruciate ligament in dogs. Veterinary Surgery, v.13, p.243-246, 1984.

VASSEUR, P.B., BERRY, C.R. Progression of stifle osteoarthrosis following reconstruction of the cranial cruciate ligament in 21 dogs. Journal of the American Animal Hospital Association, v. 28, p. 129-136, 1992.

VASSEUR, P.B., GRIFFEY, S., MASSAT, B.J. Evaluation of the Leeds-Keio synthetic replacement for the cranial cruciate ligament in dogs. An experimental study. Veterinary and Comparative Orthopedics and Traumatology, v.9, p.2937, 1996.

VASSEUR, P.B. Stifle joint. In: SLATTER, D. Textbook of small animal surgery. 2.ed. Philadelphia : Saunders, 1993. p.1817-1846. 